\title{
Pencegahan Penyakit Demam Berdarah Dengue (DBD) dengan Pembuatan Bio Spray Pengusir Nyamuk di Kelurahan Taman Sari, Ampenan, NTB
}

\section{Prevention of Dengue Haemorrhagic Fever (DHF) by Making Mosquito Repellent Bio Spray in Taman Sari, Ampenan, NTB}

\author{
Nastiti Utami ${ }^{1}$, Ari Dwi Cahyani ${ }^{2}$ \\ Sekolah Tinggi Ilmu Kesehatan Nasional, Surakarta, Indonesia \\ 1nastiti.utami@stikesnas.ac.id, ${ }^{2}$ ari17.cahyani@gmail.com
}

Riwayat Artikel: Dikirim 28 September 2020; Diterima 20 November 2020; Diterbitkan 30 November 2020

\begin{abstract}
Abstrak
Penyakit demam berdarah dengue (DBD) di Nusa Tenggara Barat tahun 2017 memiliki incidence rate per 100.000 penduduk sebesar 26,86 di atas angka nasional 22,55\% dan Case Fatality Rate 0,15\%. Pencegahan nyamuk dengan insektisida memang menjadi pilihan utama masyarakat dalam menghindari gigitan nyamuk. Produk insektisida yang beredar di masyarakat antara lain bakar, elektrik, semprot, bakar, dan lotion. Bahan-bahan kimia yang terkandung dalam insektisida anti nyamuk antara lain organoklorin, organofosfat, karbamat, piretroid, dan DEET. Bahan aktif sintetik trsebut memiliki ancaman bahaya terhadap kesehatan manusia. Hal ini melandasi pelaksanaan kegiatan Pengabdian Masyarakat Program Studi S1 Farmasi STIKES Nasional untuk pengembangan produk insektisida yang lebih aman, yaitu dengan memanfaatkan potensi alam seperti tanaman serai, cengkeh, dan daun jeruk nipis. Metode yang dilakukan adalah dengan memberikan edukasi tentang penyakit DBD, nyamuk Aedes Aegypti, dan workshop pembuatan bio spray. Hasilnya menunjukkan bahwa adanya peningkatan pengetahuan masyarakat Kelurahan Taman Sari, Ampenan, Nusa Tenggara Barat tentang upaya pencegahan penyakit DBD, ditunjukkan dengan peningkatan jawaban post-test yang benar semua, selain itu hasil evaluasi kepuasan program pengabdian masyarakat secara keseluruhan menarik.
\end{abstract}

Kata kunci: Workshop, DBD, Bio spray, NTB

\begin{abstract}
Dengue hemorrhagic fever (DHF) in West Nusa Tenggara in 2017 has an incidence rate per 100,000 population of 26.86 above the national rate of $22.55 \%$ and a Case Fatality Rate of $0.15 \%$. Prevention of mosquitoes with insecticides is the main choice for people to avoid mosquito bites. Insecticide products circulating in the community include combustion, electricity, spray, burn, and lotion. The chemicals contained in mosquito repellent insecticides include organochlorines, organophosphates, carbamates, pyrethroids, and DEET. The synthetic active ingredients pose a threat to human health. This underlies the implementation of Community Service Program from Undergraduate Programm in Pharmacy STIKES Nasional for the development of safer insecticide products use natural potentials such as lemongrass, cloves, and lime leaves. The method used is to provide education about dengue disease, the Aedes Aegypti mosquito, and a workshop by making bio spray. The results show that there is an increase in the knowledge of the people of Taman Sari, Ampenan, West Nusa Tenggara about the efforts to prevent DHF, as indicated by an increase in all correct post-test answers, In addition, the results of evaluations of overall community service satisfaction programs are very interesting.
\end{abstract}

Keywords: Workshop, DBD, Bio Spray, NTB

\section{PENDAHULUAN}

Indonesia merupakan negara yang beriklim tropis yang sangat baik untuk pertumbuhan hewan maupun tumbuhan. Selain itu, Indonesia merupakan tempat berkembangnya penyakit, terutama penyakit yang dibawa oleh vektor yaitu organisme penyebar agen patogen dari inang ke inang, seperti nyamuk. Salah satu penyakit yang dibawa oleh nyamuk yaitu Demam Berdarah Dengue (DBD). Demam Berdarah Dengue merupakan penyakit menular yang disebabkan oleh virus dengue yang ditransmisikan oleh nyamuk Aedes aegypti, 
Aedes albopictus, dan Aedes polynesiensi.

Pencegahan nyamuk dengan insektisida memang menjadi pilihan utama masyarakat dalam menghindari gigitan nyamuk. Insektisida merupakan salah satu jenis pestisida. Produk insektisida yang beredar di masyarakat antara lain bakar, elektrik, semprot, bakar, dan lotion. Bahanbahan kimia yang terkandung dalam insektisida anti nyamuk antara lain organoklorin, organofosfat, karbamat, piretroid, dan DEET.

Penggunaan insektisida memberikan manfaat terhadap pencegahan penyakit DBD, namun penggunaan produk anti nyamuk bakar dan lotion yang mengandung DEET dapat memberikan beberapa kerugian. Anti nyamuk bakar dapat menyebabkan kebakaran, selain itu efektivitas penggunaannya hanya terbatas yaitu apabila konsumen menggunakan anti nyamuk bakar di dalam ruangan. Anti nyamuk bakar mengandung racun yang dapat terhirup.

DEET merupakan bahan kimia yang bersifat korosif yang biasa digunakan dalam obat nyamuk oles, penggunaan yang terus menerus dapat menyebabkan ruam dan infeksi pada kulit, rasa panas pada kulit, lecet dan kulit melepuh. Zat aktif yang terkandung dalam bahan anti nyamuk tersebut dapat berbahaya. Hal ini dikarenakan tidak ada batasan dosis yang dapat dipakai karena tidak ada peringatan khusus misal untuk wanita yang sedang hamil atau yang memiliki gangguan pernafasan, dan penggunaan yang terus menerus akan membuat zat tersebut terakumulasi di dalam tubuh.

Bahan aktif sintetik memiliki ancaman bahaya terhadap kesehatan manusia tersebut, memberi peluang untuk pengembangan produk insektisida yang lebih aman. Selain itu, gaya hidup "kembali ke alam" dan mendukung isu global terkait peduli lingkungan, meningkatkan preferensi konsumen terhadap produk alami dan ramah lingkungan. Salah satu repellent anti nyamuk yang memanfaatkan potensi alam adalah tanaman serai, cengkeh, dan daun jeruk nipis.

Tanaman serai terutama pada daun dan batang mengandung geraniol, dsitronelol dan sitronelal hingga 36\%, sitral $0,2 \%$, dan sisanya adalah senyawa isovaleraldehid, metil neptenon, $\mathrm{d}$ sitronelal, isoamil alkohol, nerol, borneol, eugenol, geranil asetat, sitronelil asetat, sitronelil butirat, metil eugenol, disitroneloksida, alkohol-alkohol sekuiterpen, dipenten, campuran rasemik dan l-limonen, serta seskuisitronelal. Minyak cengkih dapat menolak nyamuk dengan dosis $0,1 \mathrm{ml}$ per $30 \mathrm{~cm}^{2}$. Eugenol dapat membunuh larva Aedes aegypti dengan $\mathrm{LC}_{50}$ sebesar $33 \mathrm{mg} / \ell$ dan dapat membunuh 100\% Anopheles stephensi, Aedes aegypti, dan Culex quinquefasciatus dengan dosis $7 \ell / \mathrm{ha}$ dalam waktu 30-35 menit (Mulyani, 2013).

Demam berdarah dengue muncul sebagai Kejadian Luar Biasa (KLB) dan menjadi masalah besar di masyarakat karena berisiko menyebabkan kematian serta penyebarannya yang sangat cepat. Berdasarkan data dari Kemenkes RI, angka insiden kasus Demam Berdarah Dengue di Indonesia dari tahun 2013-2016 secara umum mengalami peningkatan. Pada tahun 2013 juga meningkat menjadi 45,85\%. Hal ini berbeda ketika di tahun 2014 yang mengalami penurunan menjadi 39,80\%. Pada tahun 2015 kembali mengalami peningkatan menjadi $50,75 \%$ dan tahun 2016 meningkat secara signifikan sebesar 78,85\% (Kemenkes RI, 2018).

Menurut data Dinkes NTB tahun 2019, prevalensi demam berdarah dengue sebesar 535 kasus DBD. Demam berdarah dengue banyak terjadi di Kota Mataram yaitu sebanyak 131 orang dan prevalensi terendah di Kabupaten Sumbawa Barat yaitu sebanyak 14 orang (Dinkes NTB, 2019). Prevalensi demam berdarah yang banyak terjadi di kota Mataram perlu menjadi perhatian dan perlu dilakukan penanggulangan penyakit demam berdarah. Oleh karena itu kegiatan Pengabdian Masyarakat dengan tema Penyuluhan 
pemanfaatan bahan alam sebagai bio spray untuk mencegah penyakit DBD sangat penting dilakukan di salah satu kelurahan di Nusa Tenggara Barat. Adapun kegiatan yang dilakukan untuk menanggulangi penyakit demam berdarah berupa penyuluhan kepada masyarakat mengenai DBD dan penyampaian informasi mengenai pembuatan bio spray anti nyamuk dari bahan alam.

\section{METODE}

\section{Tahap persiapan}

Tahap ini dimulai dengan survei wilayah dan pendekatan dengan masyarakat Kelurahan Taman Sari, Kecamatan Ampenan, Nusa Tenggara Barat. Pendekatan melalui tokoh masyarakat dan mengidentifikasi masalah utama yang berkaitan dengan penyakit DBD Tahap ini bertujuan untuk menggali masalah dan problematika yang di alami oleh masyarakat di wilayah sekitar. Selain itu pendekatan kepada masyarakat juga dilakukan untuk menentukan waktu pelaksanaan acara pengabdian.

\section{Tahap pelaksanaan}

\section{Edukasi tentang Penyakit DBD (Penyuluhan)}

Pada tahap ini dilakukan penyuluhan tentang Materi yang disampaikan dalam sesi ini yaitu tentang penyakit DBD yang meliputi: ciri-ciri nyamuk pembawa virus dengue, faktor yang mempengaruhi penyebaran $\mathrm{DBD}$, lingkungan yang dapat menjadi tempat perkembangbiakan nyamuk, tanda atau gejala penyakit DBD, pencegahan dan pengendalian nyamuk DBD.

\section{Workshop tentang tanaman yang memiliki potensi sebagai pengusir nyamuk}

Pada tahap ini dilakukan penyuluhan tentang tanaman yang berpotensi sebagai pengusir nyamuk. Pada tahap ini juga diberikan leaflet kepada masyarakat untuk bisa mengaplikasikannya di rumah masingmasing

\section{Tahap Monitoring dan Evaluasi}

Monitoring dan evaluasi keberhasilan program pengabdian masyarakat ini dilakukan dengan memberikan soal pre-test sebelum penyuluhan dan post-test sesudah penyuluhan kepada peserta. Evaluasi kegiatan ini juga dilakukan dengan memberikan angket/ kuesioner kepuasan masyarakat terhadap kegiatan pengabdian yang dilakukan.

Keberhasilan kegiatan workshop dilihat dari peningkatan keterampilan peserta yang sebelumnya tidak mengetahui cara pembuatan dan pemanfaatan bahan alam untuk digunakan sebagai spray anti nyamuk. Luaran workshop ini berupa produk bio spray.

\section{HASIL DAN PEMBAHASAN}

Demam Berdarah Dengue atau DBD adalah penyakit yang ditularkan melalui gigitan nyamuk. Sebagian di antaranya mewabah secara tiba-tiba dan menjangkiti ribuan orang dalam waktu singkat. Penyakit DBD sebagai salah satu penyakit menular, sampai saat ini masih merupakan masalah kesehatan masyarakat di Provinsi NTB karena penyebarannya yang cepat, berpotensi kematian dan semua kabupaten/kota sudah pernah terjangkit DBD (Dinkes NTB, 2019).

Pengabdian masyarakat ini dilaksanakan dalam bentuk penyuluhan tentang DBD dan penjelasan pembuatan bios pray pengusir nyamuk. Kegiatan ini diberikan kepada masyarakat agar kesadaran untuk mencegah perkembangbiakan nyamuk penyebab demam berdarah dan dapat melakukan pencegahan agar tidak terjadi gigitan nyamuk. Penyuluhan dan workshop ini dilaksanakan di Kelurahan Taman Sari, Kecamatan Ampenan, Nusa Tenggara Barat dengan jumlah peserta 32 orang.

\section{Edukasi tentang Pencegahan DBD}

Nyamuk Aedes Aegypti bersifat anthropofilik, artinya nyamuk tersebut lebih memilih untuk menghisap darah manusia. Selain itu, juga bersifat multiple feeding, artinya 
bisa menghisap darah beberapa kali. Virus ini terdapat pada kelenjar air liur nyamuk yang terinfeksi. Virus berpindah bersama air liur nyamuk ketika nyamuk menggigit manusia. Reaksi selanjutnya yang didapatkan oleh orang yang tergigit nyamuk ini bergantung pada kekebalan tubuhnya. Jika kekebalan tubuh baik, maka virus tersebut tidak memunculkan gejala apa pun pada tubuh. Sementara itu, jika kekebalan tubuh menurun, maka gejala demam dengue pun dapat timbul, sehingga mempengaruhi peningkatan risiko penularan demam dengue di wilayah perumahan dengan penduduk yang padat.

Gambar 1.

Dokumentasi edukasi
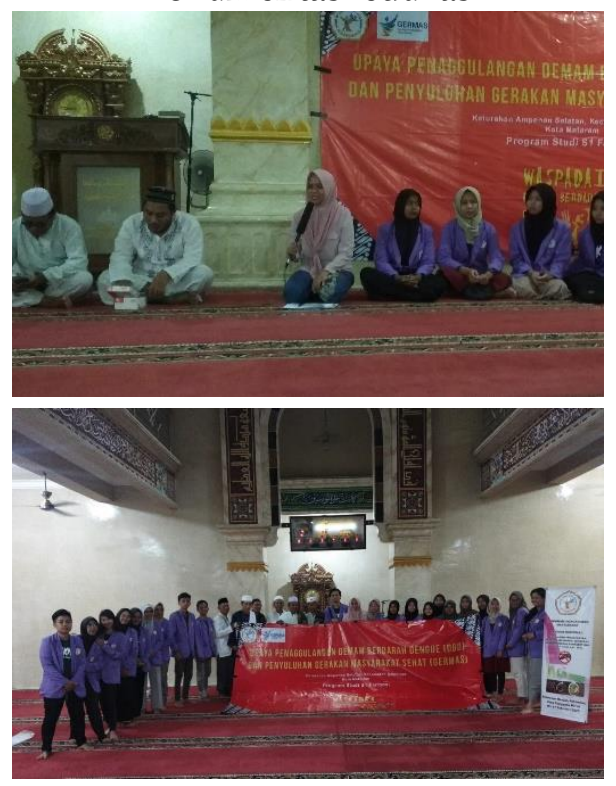

Sumber: dokumentasi pribadi

Bahan alam yang dapat digunakan untuk mengobati penyakit DBD yaitu pepaya gandul, kunyit, temu ireng, meniran, dan daun jambu biji. Tanaman tersebut diramu sedemikian rupa, baik dalam bentuk simplisia kering, serbuk, maupun sirup. Jenis tanaman tersebut dipilih berdasarkan manfaatnya dalam mengatasi penyebab penyakit DBD dan gejalanya. Tanaman tersebut sudah digunakan secara empiris sebagai obat tradisional, telah diketahui kandungan zat berkhasiat dan golongan senyawa atau zat identitasnya.
Daun pepaya mengandung berbagai enzim seperti papain, karpain, pseudokarpain, nikotin, kontinin, miosmin, dan glikosida karposid. Hasil penelitian mengenai khasiat daun pepaya menunjukkan bahwa papain pada daun pepaya memiliki efek terapi pada penderita inflamasi atau pembengkakan organ hati, mata, kelamin, dan usus halus. Pembengkakan organ hati ditemukan pada penderita demam berdarah (Bermawie, 2006).

Meniran memiliki khasiat sebagai obat antivirus. Senyawa yang ditemukan pada meniran antara lain adalah triterpenoid, flavoniod, tanin, alkaloid, dan asam fenolat. penelitian menunjukkan bahwa meniran berfungsi menghambat DNA polimerase dari virus hepatitis B dan virus hepatitis sejenisnya, menghambat enzim reverse transcriptase dari retrovirus, sebagai antibakteri, antifungi, antidiare, dan penyakit gastrointestinal lainnya (Bermawie, 2006).

Rimpang kunyit mengandung minyak atsiri (turmeron, zingiberene) dan zat berkhasiat dari golongan kurkuminoid (kurkumin I, II, dan III). Hasil penelitian menunjukkan bahwa kunyit memiliki aktivitas sebagai antimikroba (berspektrum luas), antivirus HIV, antioksidan, antitumor (menginduksi apostosis), menghambat perkembangan sel tumor payudara (Bermawie, 2006).

Temu ireng telah banyak dimanfaatkan secara empiris untuk mengobati sel-sel hati yang rusak. Pada penderita demam berdarah, terjadi kerusakan sel-sel hati. Temu ireng mengandung minyak atsiri (turmeron, zingiberene), kurkuminoid (kurkumin I, II, dan III) serta alkaloid, saponin, pati, damar, dan lemak (Bermawie, 2006).

Daun jambu biji mengandung tanin, minyak atsiri, minyak lemak, dan minyak malat, sedangkan buahnya mengandung vitamin $C$ yang tinggi. Hasil penelitian yang dikutip dari berbagai sumber menunjukkan daun jambu biji terbukti dapat menghambat 
aktivitas enzim reverse transcriptase dari virus dengue, tanin menghambat enzim reverse transcriptase maupun DNA polymerase dari virus serta menghambat pertumbuhan virus yang berinti DNA maupun RNA (Bermawie, 2006).

Selain pengobatan ternyata tanaman yang ada di sekitar masyarakat pun dapat dimanfaatkan untuk pencegahan gigitan nyamuk seperti daun serai. Tanaman serai merupakan tanaman tanah tandus dan tidak membutuhkan pemupukan yang intensif. Panen pertama dilakukan 6-8 bulan setelah penanaman. Panen berikutnya dapat dilakukan dalam jarak 3-4 bulan. Panen dilakukan setelah siang hari (sore) dan tidak pada saat hujan. Hal tersebut bertujuan untuk memperoleh metabolit sekunder yang optimum sebagai zat aktif untuk pengusir nyamuk.

\section{Workshop Pembuatan Spray Anti Nyamuk}

Pemanfaatan bahan alam sekitar juga diterapkan dalam acara ini. Mahasiswa memandu pembuatan bio spray anti nyamuk kepada masyarakat.

Gambar 2.

Dokumentasi workshop pembuatan bio spray

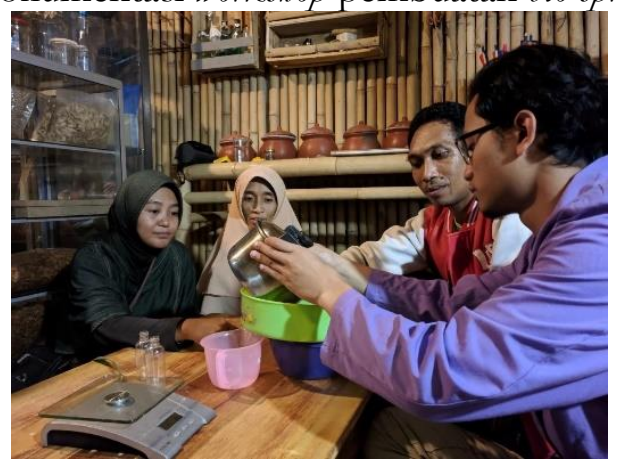

Sumber: dokumentasi pribadi

Pembuatan spray anti nyamuk yaitu dengan menyiapkan batang serai sebanyak 10 gram dengan 2 batang cengkeh yang tidak terlalu tua ataupun muda sebanyak 10 gram atau setara dengan 12 lembar daun cengkeh. Masing-masing dimasukkan dalam panci kecil dan ditambahkan $100 \mathrm{~mL}$ air atau setara dengan 1 gelas, panci kecil ditutup rapat dan dikukus pada air yang mendidih selama 15 menit, biarkan sampai mendingin, saring hingga diperoleh infusa. Infusa yang didapat dicampur dan dimasukkan dalam botol spray, untuk mengurangi aroma kuat dari cengkeh bisa ditambahkan daun jeruk purut. Penggunaan spray repellent nyamuk dengan cara menyemprotkan pada bagian tubuh yang rentan terhadap gigitan nyamuk atau disemprotkan di ruangan.

Gambar 3.

Proses workshop pembuatan produk bio spray

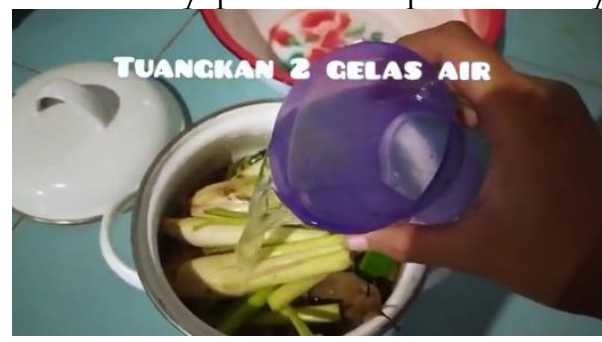

(1)

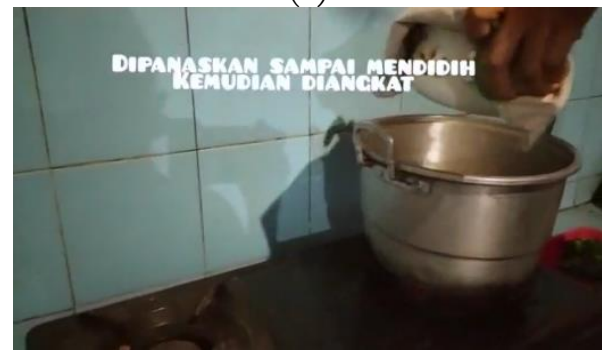

(2)

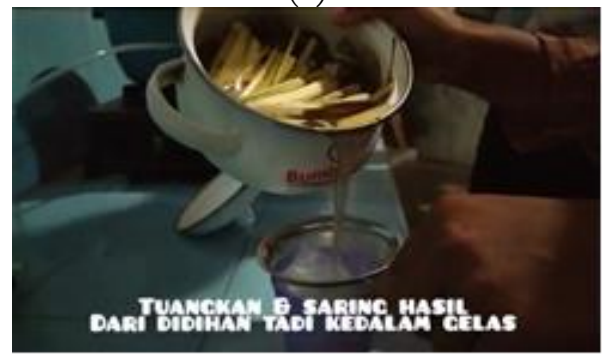

(3)

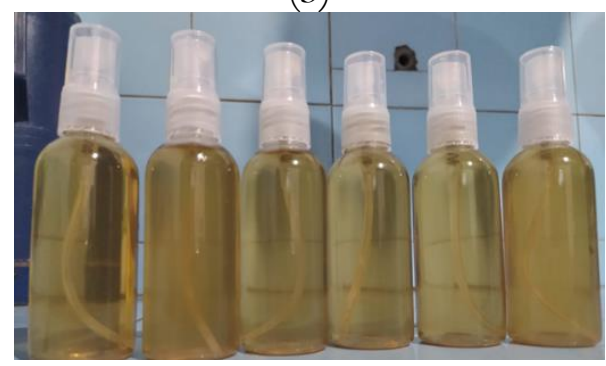

(4)

Sumber: dokumentasi pribadi 
Berdasarkan uji penetapan kadar minyak atsiri didalam ekstrak daun cengkeh, daun jeruk purut dan daun serai, terbukti daun serai dan kulit jeruk purut mengandung minyak atsiri. Pada percobaan tersebut pula diketahui kadar minyak atsiri pada daun jeruk purut dan serai relatif kecil. Hal ini disebabkan saat proses pengeringan, kandungan minyak atsiri ikut menguap (Mulyani, dkk., 2013).

Kandungan minyak atsiri dalam daun serai, cengkeh, dan daun jeruk dapat sebagai pengusir nyamuk adalah dengan cara pelepasan bau dan senyawa repellent yang terdapat pada minyak atsiri. Kulit manusia mengeluarkan asam laktat dan produk ekskresi yang dapat digunakan nyamuk untuk mendeteksi bau dan keberadaan manusia. Ketika minyak atsiri dioleskan pada kulit manusia, minyak atsiri tersebut terserap ke dalam pori-pori kulit dan menguap dengan adanya panas tubuh sehingga menghasilkan bau yang terdeteksi oleh reseptor nyamuk.

Bau ini tidak disenangi nyamuk, sehingga nyamuk akan memberikan respons agar nyamuk menghindar dari bau tersebut. Minyak atsiri juga bekerja dengan cara menutupi bau pada manusia sehingga reseptor-reseptor pada alat indra tersebut terganggu dan nyamuk tidak dapat mendeteksi produk kimiawi dari manusia (Hidayat, 2010).

Efektivitas bio spray. Berdasarkan syarat mutu efektivitas penolakan yang ditetapkan SNI untuk produk anti nyamuk yang menggunakan bahan aktif sintetik adalah $80 \%$. efektivitas penolakan dari anti nyamuk yang dihasilkan pada formulasi bahan alam berada pada kisaran 53,8\% hingga 84,78\% (Nuriyah, 2013).

\section{Evaluasi Kegiatan}

Kegiatan program pengabdian masyarakat ini diakhiri post-test dengan pertanyaan yang sama dengan pertanyaan pada pre-test. Hasil post-test ini menunjukkan adanya peningkatan pemahaman peserta tentang cara pencegahan DBD.

Peserta penyuluhan mengalami peningkatan pengetahuan yang cukup signifikan. Jawaban salah untuk soal pre-test dari peserta dikarenakan tidak dijawab, hasil wawancara singkat dikarenakan peserta tidak pernah mengetahuinya. Pertanyaan mengenai gejala awal DBD dan cara pencegahan umumnya masyarakat sudah memahaminya apabila dilihat hasil persentase jawaban salah hanya 13,33\% pada soal pre-test, namun jawaban salah soal pre-test yaitu $>50 \%$ berbeda secara signifikan dengan pengetahuan masyarakat tentang bahan alam yang dapat dimanfaatkan untuk pengobatan dan pencegahan DBD dan cara pembuatan bio spray anti nyamuk.

Bahan alam yang banyak diketahui dalam pengobatan DBD adalah jus jambu biji merah. Penjelasan pada penyuluhan bahwa buah jambu biji merah dapat digunakan untuk mempercepat penyembuhan DBD karena buah tersebut memiliki kandungan vitamin $C$ yang tinggi sehingga baik untuk meningkatkan kekebalan tubuh dan perbaikan sel-sel yang rusak. Masyarakat belum banyak mengetahui tentang tanaman-tanaman sekitar atau rempah yang sering digunakan sebagai bumbu dapur ternyata dapat digunakan untuk pengusir nyamuk.

Penyuluhan edukasi dan workshop berjalan dengan antusias masyarakat yang tinggi, sehingga banyak pertanyaan yang diajukan mengenai pencegahan DBD, Berdasarkan jawaban hasil post-test diperoleh hasil yang lebih baik yaitu semua jawaban singkat ataupun uraian dijawab dengan benar semua, maka dapat dikatakan bahwa penyuluhan maupun penjelasan workshop yang akan dilakukan berhasil memberikan pengetahuan kepada masyarakat lebih dalam tentang pencegahan penyakit DBD dengan pemanfaatan bahan alam untuk mencegah gigitan nyamuk. 
Gambar 4.

Grafik hasil evaluasi kepuasan peserta terhadap program pengabdian masyarakat

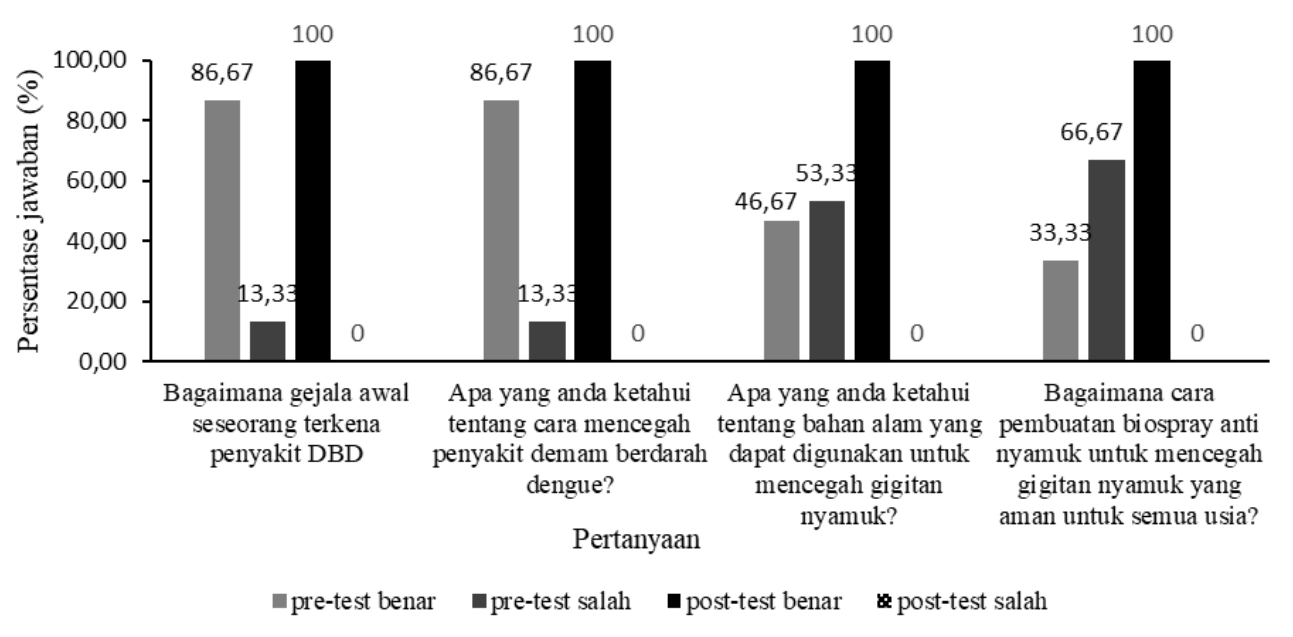

\section{KESIMPULAN}

Kegiatan ini memberikan peningkatan pengetahuan masyarakat di sekitar pemukiman Kelurahan Taman Sari, Kecamatan Ampenan, Nusa Tenggara Barat yang dibuktikan dengan peningkatan hasil pre-test ke post-test. Kegiatan ini juga dapat menghasilkan produk bio spray sebagai pengusir nyamuk yang dapat digunakan oleh masyarakat di lingkungan tersebut, serta dapat memanfaatkan lahan yang sebelumnya kosong dan tidak dimanfaatkan menjadi taman kecil yang berisi tanaman bahan baku pembuatan bio spray anti nyamuk.

\section{DAFTAR PUSTAKA}

Bermawie, Nurliani. (2006). Mengatasi Demam Berdarah dengan Tanaman Obat. Jurnal Warta Penelitian Dan Pengembangan Pertanian, 28(6), 6-8. Dinkes NTB. (2019). Profil Kesehatan NTB 2018 (Vol. 53). Retrieved from https://doi.org/10.1017/CBO97811 07415324.004.

Hidayat, Meilinah, Rosnaeni, dan Katrin Fitria Hendranata. 2010. Efek repelen minyak lavender, minyak mawar dan minyak rosemari terhadap nyamuk Aedes aegypti. Jurnal Medika Planta.
1(1): 67-74.

Kementerian Kesehatan RI. (2018). Situasi Penyakit Demam Berdarah Di Indonesia 2017 (Vol. 31). Retrieved from https://doi.org/10.3376/10811710(2006)31[71:aomtva]2.0.co;2

Mulyani, S., Mulyaningsih, B., Lestari, A. W., M, F. A., \& S, D. S. A. (2013). Lemongrass, Cloves, Orange leaves as Insence Combustible for Aedes Aegypti Repellant. Traditional Medicine Journal, 18(September), 195-200.

Nuriyah, N. (2011). Aplikasi Minyak Daun Cengkih dan Minyak Serai Wangi sebagai Bahan Aktif Antiserangga Alami. Srkripsi. Retrieved from https://repository.ipb.ac.id/jspui/bit stream/123456789/52090/1/F11nn u.pdf. 